\title{
Influence of Cluster Thinning on Return Bloom, Nut Quality, and Concentrations of Potassium, Nitrogen, and Non-structural Carbohydrates
}

\author{
Charles T. Rohla ${ }^{1}$, Michael W. Smith ${ }^{2}$, and Niels O. Maness \\ Department of Horticulture \& Landscape Architecture, Oklahoma State University, Stillwater, \\ OK 74078
}

\begin{abstract}
AdDitional index words. Carya illinoinensis, fruit, fruit number, kernel development, nut size, kernel percentage, flowering, irregular bearing

Abstract. Alternate bearing pecan trees [Carya illinoinensis (Wangenh.) C. Koch] were hand-thinned annually to 1, $\leq \mathbf{2}$, or $\leq \mathbf{3}$ fruit/cluster or not thinned when the ovule was about one-half expanded. Return bloom was monitored on (1) vegetative shoots, (2) bearing shoots without a second growth flush in the terminal position on 1-year-old branches, (3) bearing shoots without a second growth flush in the lateral position on 1-year-old branches, and (4) bearing shoots with a second growth flush that were primarily in the terminal position. Yield and nut quality were determined in addition to nonstructural carbohydrate, organically bound nitrogen $(N)$, and potassium $(K)$ concentrations in the roots and shoots during January. Fruit thinning improved return bloom but had little effect on weight/nut, kernel percent, or kernel grade. Fruit thinning had either a modest or no effect on nonstructural carbohydrates, organically bound $N$, and $K$ concentrations. Vegetative shoots and bearing terminal shoots produced a similar number of flowers/ 1-year-old branch and percentage of flowering current-season shoots. Bearing lateral shoots produced fewer flowers than vegetative shoots most years and fewer flowering current-season shoots during one year. Shoots with a second growth flush produced more flowers/1-year-old branch and a larger percentage of flowering current-season shoots than did vegetative shoots 2 of 3 years. These data indicate fruit thinning of overloaded trees improved return bloom, but the lack of interactions between thinning treatment and shoot type suggests that the number of fruit/cluster was less important than total crop load in determining nut quality and return bloom. Thus removal of entire fruit clusters appears as effective as thinning fruit within a cluster to maintain adequate nut quality and promote return bloom. Nonstructural carbohydrates, organically bound $N$, and $K$ were not limiting factors in bearing consistency because they were not depressed in unthinned trees. Nonstructural carbohydrates, organically bound $\mathrm{N}$, and $\mathrm{K}$ concentrations were not closely linked to alternate bearing because return bloom was enhanced by thinning, but thinning did not affect their concentrations.
\end{abstract}

Alternate bearing is the most significant horticultural problem facing pecan producers. Several reviews have been published on the subject (Barnett and Mielke, 1981; Monselise and Goldschmidt, 1982; Smith, 2005; Sparks, 1974, 1975, 1979, 1986, 2000, 2003a; Wood, 1991; Wood et al., 2004). Initial research (Smith and Waugh, 1938) and later work suggested that stored carbohydrate concentrations during the winter markedly affected subsequent flowering (Malstrom, 1974; Wood, 1989, 1991; Worley, 1979a, 1979b). Other work suggested that inhibition of return bloom by developing fruit was incited by phytohormones or other growth regulators (Amling and Amling, 1983; Smith et al., 1986; Wood, 2003; Wood and McMeans, 1981; Wood et al., 2003). Hypotheses for alternate bearing have undergone modification as more data became available. The current theory supports a two-level control with inhibitors and promoters determining induction during the previous growing season and the dormant season carbohydrate pool influencing pistillate flower development

Received for publication 17 May 2006. Accepted for publication 16 July 2006. Approved for publication by the Oklahoma Agricultural Experiment Station. Funding for this study was provided by the Oklahoma Agricultural Experiment Station, U.S.D.A. Crop Germplasm Committee, and the Oklahoma Pecan Growers' Association.

${ }^{1}$ Graduate Student. Current address: Samuel Roberts Noble Foundation, Ardmore, OK 73402.

${ }^{2}$ Regents Professor. Corresponding author: E-mail: mike.smith@okstate.edu.
(Smith et al., 1986; Sparks, 2000, 2003a; Wood, 2003; Wood and McMeans, 1981; Wood et al., 2003, 2004).

Nitrogen application has generally increased pecan yield (Brooks and Livingston, 1962; Hunter, 1964; Hunter and Hammar, 1947, 1961; Skinner, 1922; Smith and Hamilton, 1937; Smith et al., 1985; Sparks, 1968; Taylor, 1930; Worley, 1974, 1990); however, Sparks (2003b) has pointed out that alternate bearing tendency was frequently increased. A recent $\mathrm{N}$ management strategy is an early spring $\mathrm{N}$ application followed by a late summer or fall $\mathrm{N}$ application during years with large crops (Goff et al., 2001; Wood, 2001a). The hypothesis guiding this strategy is that the $\mathrm{N}$ demand by large crops creates a critical $\mathrm{N}$ shortage during the late summer and fall as the crop matures. This $\mathrm{N}$ shortage that develops in the fall when crops are large may contribute to alternate bearing.

There are conflicting reports regarding the benefit of fall $\mathrm{N}$ application. Acuña-Maldonado et al. (2003) reported the greatest $\mathrm{N}$ absorption between budbreak and the end of shoot expansion, with little absorption between the end of leaf expansion and leaf fall. Kraimer et al. (2004) later reported that $\mathrm{N}$ applied during the kernel filling stage was strongly absorbed. The newly absorbed $\mathrm{N}$ replenished endogenous $\mathrm{N}$ reserves and might moderate pecan alternate bearing.

Nonstructural carbohydrates and organically bound $\mathrm{N}$ must be transported from a source or storage site (net exporter) to a sink (net importer) via the phloem. Adequate $\mathrm{K}$ favors phloem loading by improving ATP synthesis, a high-energy source 
required for phloem loading (Haeder, 1977; Mengel, 1980). Potassium also increases flux rates without diluting phloem sap content of organic solutes (Mengel, 1980; Mengel and Haeder, 1977), thus transport rates are faster when adequate $K$ is available. Thus, it appears that $\mathrm{K}$ may affect both phloem loading and phloem transport (Haeder, 1977; Vreugdenhil, 1985).

In pecan, $\mathrm{K}$ accumulated quickly during the final $30 \mathrm{~d}$ before the fruit ripened, when the cotyledons were rapidly developing (Diver and Smith, 1984). Most of the kernel weight was accumulated during this period. Kernel oil content was strongly correlated with leaf $\mathrm{K}$ concentration (Hunter and Hammar, 1956). Developing fruit substantially depressed leaf K concentration during the latter part of the growing season (Diver and Smith, 1984; Krezdorn, 1955; Sparks, 1977), suggesting that K may become limiting when crop loads are large. Adequate K supplies appear critical to the transport and delivery of sugars and $\mathrm{N}$ compounds and are more likely to be limiting during years with large crops.

One method to combat alternate bearing and improve nut quality during large crop years is mechanical fruit thinning (Smith and Gallott, 1990). Reid et al. (1993) demonstrated that fruit thinning while the fruit were between one-half and full ovule expansion in the liquid endosperm developmental stage reduced alternate bearing. Crop load thresholds based on the percentage of fruiting shoots and fruit size have been established for various cultivars (Smith et al., 1993). However, information is lacking on the effect of cluster size on alternate bearing and nut quality. Uncertainty remains regarding the need to account for cluster size in crop load threshold recommendations for mechanically thinning pecan trees.

One objective in this study was to determine the effect of thinning trees to different cluster sizes on return bloom and nut quality. Another objective was to determine the relationship of trees thinned to different cluster sizes on dormant-season nonstructural carbohydrates, organically bound $\mathrm{N}$, and $\mathrm{K}$ concentrations. Also characterized was the fruiting potential of different shoot types based on their previous year's fruiting, position on the branch, and the presence or absence of a second growth flush.

\section{Materials and Methods}

Twelve 13-year-old 'Pawnee' trees growing in a Teller sandy loam (fine-loamy, mixed, active, thermic, Udic Argiustolls) in a commercially managed orchard near Charlie, Texas, were selected on the basis of uniformity of size, vigor, crop load ( $85 \%$ to $90 \%$ bearing shoots), and location within the orchard. Trees were spaced $12.2 \times 12.2 \mathrm{~m}$ apart with $19.7 \pm 2.1-\mathrm{cm}-$ diameter trunks measured $1.4 \mathrm{~m}$ above the ground.

The entire orchard floor was maintained vegetation-free throughout the growing season with glyphosphate. Trees received supplemental irrigation from microsprinklers during April through October. Urea was surface-applied in 2001 in a split application at rates of $112 \mathrm{~kg} \cdot \mathrm{ha}^{-1} \mathrm{~N}$ in March, $112 \mathrm{~kg} \cdot \mathrm{ha}^{-1}$ $\mathrm{N}$ in June, and $84 \mathrm{~kg} \cdot \mathrm{ha}^{-1} \mathrm{~N}$ in October. Water samples taken during 2001 revealed that the groundwater used for irrigation was contaminated with $34 \mathrm{mg} \cdot \mathrm{L}^{-1} \mathrm{NO}_{3}-\mathrm{N}$. In subsequent years, trees received only the $\mathrm{N}$ from contaminated irrigation water. This resulted in the application of $141 \mathrm{~kg} \cdot \mathrm{ha}^{-1} \mathrm{~N}$ in 2002 and $191 \mathrm{~kg} \cdot \mathrm{ha}^{-1} \mathrm{~N}$ in 2003. Zinc was applied five times between budbreak and July each year at $2.4 \mathrm{~kg} \cdot \mathrm{ha}^{-1} \mathrm{Zn}$ from $36 \% \mathrm{ZnSO}_{4}$.
Pest management followed extension recommendations for a commercial orchard (von Broembsen and Mulder, 2005).

Entire trees were hand thinned annually to $1, \leq 2$, or $\leq 3$ fruit/cluster or not thinned when the ovule was about one-half expanded in early August. The thinning treatments of 2 or 3 fruit/cluster had some clusters on the tree that were naturally smaller than our thinning target; hence the designation of $\leq 2$ or $\leq 3$ fruit/cluster. Trees retained the same thinning treatment throughout the study. In 2001 when the study was initiated, the trees had about the same crop load at the time of thinning. Thus, the crop load was reduced in proportion to the thinning treatment. However, in subsequent years the initial crop load varied among thinning treatment; therefore, thinning the entire trees to the specified cluster sizes was not necessarily related to total tree crop load.

Return bloom was monitored for each thinning treatment on four shoot types: (1) vegetative shoots, (2) bearing shoots without a second growth flush in the terminal position on 1year-old branches, (3) bearing shoots without a second growth flush in the lateral position on 1-year-old branches, and (4) bearing shoots with a second growth flush primarily in the terminal position. Thirty shoots per tree of each type were tagged at shuck split to monitor return bloom. Shoots of each type were selected at random throughout the canopy. The following spring the number of dead 1-year-old branches, new shoots/1-year-old branch, pistillate flowers produced/1-yearold branch, cluster size, and the percentage of current-season shoots flowering on each type of 1-year-old tagged branch were determined.

Total yield per tree was measured annually. Forty nut samples were collected at random from each tree, and nut weight, kernel percentage, and kernel grade were determined. Kernel grade was based on a scale from 1 to 4 , with $1=$ wellfilled, bright yellow kernel; 2 = bright yellow kernel but lacking plumpness of a number 1 kernel; 3 = an amber kernel that may or may not be well filled; and $4=$ reject.

In January, while trees were dormant, root and shoot samples were collected. Roots were separated into samples of $<1 \mathrm{~cm}$ and $\geq 1 \mathrm{~cm}$ in diameter and then washed in tap water to remove adhering soil. The four shoot types, described earlier, were collected from the canopy periphery. Shoots with a secondary growth flush were divided into the primary shoot and the second growth flush. Roots and shoots were stored at $0{ }^{\circ} \mathrm{C}$ until they were freeze-dried to a constant weight. Samples were then ground in a Wiley mill to pass through a 20 -mesh screen, and then stored in an airtight glass jar at $0{ }^{\circ} \mathrm{C}$ until analyzed. Organically bound $\mathrm{N}$ was analyzed by the macro-Kjeldahl method (Horowitz, 1980), and K was analyzed using atomic absorption spectroscopy. Nonstructural carbohydrates (starch, reducing and nonreducing sugars) were determined using Nelson's modification of Somogyi's method (Hodge and Hofreiter, 1962), which has been used to analyze nonstructural carbohydrates in pecan tissue (Smith et al., 1986; Wood, 1984, 1989).

Fruit cluster thinning treatment was replicated three times using single-tree replicates. The experimental design was completely randomized with each tree serving as a replication for the variables yield, nut size, kernel yield and grade, and carbohydrate, $\mathrm{N}$, and $\mathrm{K}$ concentrations. When the influence of shoot type was considered on return bloom, the data were analyzed as a split plot with shoot type nested within thinning treatment, and the 30 shoots of each type served as subsamples. 
Main effects and interactions were tested using analysis of variance followed by Duncan's multiple range test where appropriate.

\section{Results}

Yield data, averaged by treatment, indicated that the 2002 crop on unthinned trees was $20 \%$ larger than the 2001 crop and $11 \%$ larger than the 2003 crop (Table 1). This suggests that alternate bearing was beginning in this orchard, but alternation was mild compared with older orchards. However, variation in yield was substantially greater on individual trees than the yield averages suggested. Yield of unthinned trees ranged from $63 \%$ greater to $41 \%$ less in 2002 compared with 2001 (Fig. 1). The 2002 crop on unthinned trees ranged from $42 \%$ greater to $78 \%$ less than the 2003 crop. Thus, individual trees clearly displayed severe alternate bearing (Fig. 1), although the average yields (Table 1) suggested that alternate bearing was not extreme because individual trees had different patterns among years.

There were no differences in death of tagged shoots among thinning treatments and shoot types (data not shown). Over $98 \%$ of the shoots survived and produced new growth the following spring.

Thinning treatments did not affect nut weight, or the response was inconsistent (Table 2). Kernel percentage in 2004 was greater when clusters were thinned to 1 fruit/cluster than when clusters were not thinned. Kernel percentage was unaffected by treatment the other 2 years. Fruit thinning did not affect kernel grade.

The number of current-season shoots produced per 1-yearold branch was unaffected by thinning treatment (data not shown). Cluster size the next year was also unaffected by thinning treatment (data not shown). However, in 2002 and 2004, fruit thinning increased the number of pistillate flowers/

Table 1. Influence of fruit thinning treatment on pecan yield.

\begin{tabular}{lcccl}
\hline \multirow{2}{*}{$\begin{array}{l}\text { Fruit cluster } \\
\text { thinning treatment }\end{array}$} & \multicolumn{4}{c}{ Yield $\pm \mathrm{SD}(\mathrm{kg} / \mathrm{tree})$} \\
\cline { 2 - 5 } (fruit/cluster) & 2001 & 2002 & 2003 & Cumulative \\
\hline Unthinned & $15.0 \pm 4.5$ & $17.9 \pm 8.1$ & $16.1 \pm 2.9$ & $49.1 \pm 9.3$ \\
$\leq 3$ & $13.8 \pm 13.8$ & $29.5 \pm 3.2$ & $10.9 \pm 6.1$ & $54.3 \pm 11.5$ \\
$\leq 2$ & $9.2 \pm 4.5$ & $21.9 \pm 4.9$ & $11.7 \pm 3.5$ & $42.7 \pm 12.4$ \\
1 & $6.4 \pm 0.7$ & $15.0 \pm 1.4$ & $11.6 \pm 1.1$ & $32.9 \pm 1.8$ \\
\hline
\end{tabular}

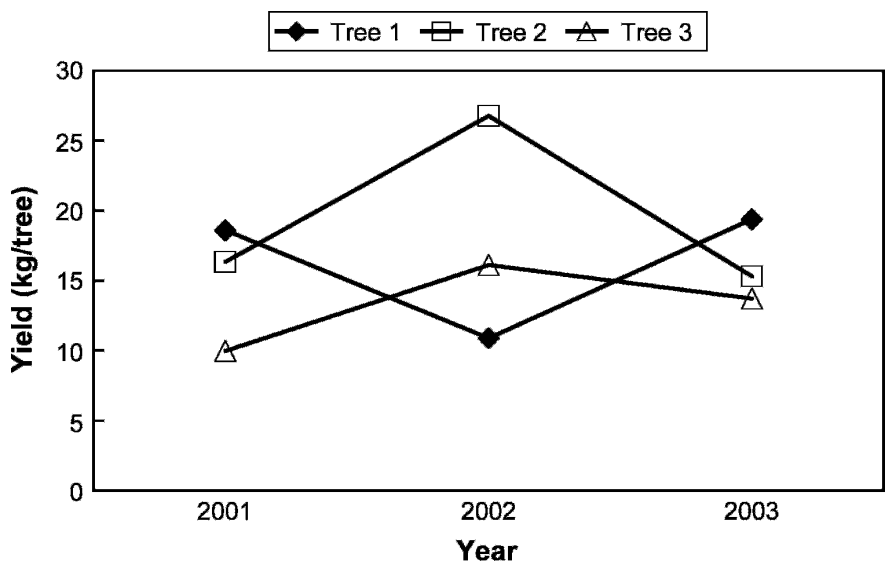

Fig. 1. Yield of 'Pawnee' pecan trees in the unthinned treatment. 1-year-old branch (Table 3). In 2003, only trees thinned to 1 fruit/cluster produced more flowers/1-year-old branch than the unthinned trees or the other thinning treatments.

In 2002, a significant interaction existed between fruit thinning treatment and shoot type affecting the percentage of flowering current-season shoots (Table 4). Bearing terminal shoots on unthinned trees or those thinned to $\leq 3$ fruit/cluster produced $42 \%$ and $26 \%$ fewer flowering current-season shoots, respectively, than shoots that had been vegetative. However, when trees were thinned to $\leq 2$ or 1 fruit/cluster, the bearing terminal shoots produced $11 \%$ and $15 \%$ more flowering current-season flowering shoots, respectively, than did shoots that had been vegetative. Bearing lateral shoots compared with vegetative shoots produced $64 \%, 26 \%$, and $2 \%$ less and $4 \%$ more flowering current-season shoots on unthinned trees and those thinned to $\leq 3, \leq 2$, and 1 fruit/cluster, respectively. This suggests that reducing the number of fruit per cluster could result in a greater return bloom than reducing the number of flower clusters. However, there were no interactions between cluster thinning treatment and shoot type affecting the flowering current-season shoots in 2003 and 2004 (interaction

Table 2. Influence of pecan fruit cluster thinning on nut weight, kernel percentage, and kernel grade.

\begin{tabular}{lccc}
\hline $\begin{array}{l}\text { Fruit cluster thinning } \\
\text { treatment (fruit/cluster) }\end{array}$ & 2002 & 2003 & 2004 \\
\hline \multirow{3}{*}{ Unthinned } & $8.6 \mathrm{a}^{\mathrm{z}}$ & Wt $(\mathrm{g} / \mathrm{nut})$ \\
$\leq 3$ & $7.4 \mathrm{~b}$ & $9.0 \mathrm{a}$ & $8.5 \mathrm{a}$ \\
$\leq 2$ & $8.1 \mathrm{ab}$ & $8.7 \mathrm{a}$ & $8.9 \mathrm{a}$ \\
1 & $8.2 \mathrm{ab}$ & $8.6 \mathrm{a}$ & $8.1 \mathrm{a}$ \\
& & Kernel content $(\%)$ \\
Unthinned & $58.44 \mathrm{a}$ & $57.23 \mathrm{a}$ & $54.26 \mathrm{~b}$ \\
$\leq 3$ & $56.60 \mathrm{a}$ & $56.88 \mathrm{a}$ & $55.06 \mathrm{ab}$ \\
$\leq 2$ & $56.51 \mathrm{a}$ & $57.12 \mathrm{a}$ & $55.47 \mathrm{ab}$ \\
1 & $58.86 \mathrm{a}$ & $57.58 \mathrm{a}$ & $57.09 \mathrm{a}$ \\
& & Kernel grade \\
Unthinned & $1.2 \mathrm{a}$ & $1.0 \mathrm{a}$ & $1.3 \mathrm{a}$ \\
$\leq 3$ & $1.4 \mathrm{a}$ & $1.0 \mathrm{a}$ & $1.2 \mathrm{a}$ \\
$\leq 2$ & $1.1 \mathrm{a}$ & $1.0 \mathrm{a}$ & $1.3 \mathrm{a}$ \\
1 & $1.1 \mathrm{a}$ & $1.1 \mathrm{a}$ & $1.2 \mathrm{a}$ \\
\hline
\end{tabular}

${ }^{\mathrm{z}}$ Means in columns within variables followed by the same letter are not significantly different by Duncan's multiple range test, $5 \%$ level. 'Kernel grades: 1 = well-filled, bright yellow kernel; $2=$ bright yellow kernel, but lacking plumpness of a number 1 kernel; $3=$ an amber kernel that may or may not be well filled; $4=$ reject.

Table 3. Influence of pecan fruit cluster thinning on subsequent year's total flowers produced from 1-year-old branches and the percentage of current-season shoots flowering.

\begin{tabular}{|c|c|c|c|c|c|}
\hline \multirow{2}{*}{$\begin{array}{l}\text { Fruit cluster } \\
\text { thinning treatment } \\
\text { (fruit/cluster) }\end{array}$} & \multicolumn{3}{|c|}{$\begin{array}{c}\text { Pistillate } \\
\text { flowers/1-yr-old } \\
\text { branch (no.) } \\
\end{array}$} & \multicolumn{2}{|c|}{$\begin{array}{l}\text { Current-season } \\
\text { shoots } \\
\text { flowering }(\%)\end{array}$} \\
\hline & 2002 & 2003 & 2004 & 2003 & 2004 \\
\hline Unthinned & $3.3 \mathrm{~b}^{\mathrm{z}}$ & $3.6 \mathrm{~b}$ & $4.8 \mathrm{~b}$ & $40 \mathrm{ab}$ & $39 \mathrm{~b}$ \\
\hline$\leq 3$ & $8.3 \mathrm{a}$ & $1.9 \mathrm{~b}$ & $7.5 \mathrm{a}$ & $23 \mathrm{~b}$ & $57 \mathrm{ab}$ \\
\hline$\leq 2$ & $7.6 \mathrm{a}$ & $3.8 \mathrm{~b}$ & $7.4 \mathrm{a}$ & $42 \mathrm{a}$ & $56 \mathrm{ab}$ \\
\hline 1 & $8.1 \mathrm{a}$ & $5.7 \mathrm{a}$ & $7.5 \mathrm{a}$ & $57 \mathrm{a}$ & $61 \mathrm{a}$ \\
\hline
\end{tabular}

${ }^{\mathrm{z}}$ Means within columns followed by the same letter are not significantly different by Duncan's multiple range test, $5 \%$ level. 
Table 4. Influence of pecan fruit cluster thinning and shoot type on the percentage of flowering current-season shoots in 2002.

\begin{tabular}{|c|c|c|}
\hline $\begin{array}{l}\text { Fruit cluster } \\
\text { thinning } \\
\text { treatment } \\
\text { (fruit/cluster) } \\
\end{array}$ & Previous yr shoot type & $\begin{array}{l}\text { Current-season } \\
\text { shoots } \\
\text { flowering }(\%)\end{array}$ \\
\hline \multirow[t]{4}{*}{ Unthinned } & Vegetative & 50 \\
\hline & Fruiting, terminal position & 29 \\
\hline & Fruiting, lateral position & 18 \\
\hline & $\begin{array}{l}\text { Fruiting with a second } \\
\text { growth flush }\end{array}$ & 31 \\
\hline \multirow[t]{4}{*}{$\leq 3$} & Vegetative & 74 \\
\hline & Fruiting, terminal position & 55 \\
\hline & Fruiting, lateral position & 55 \\
\hline & $\begin{array}{l}\text { Fruiting with a second } \\
\text { growth flush }\end{array}$ & 67 \\
\hline \multirow[t]{4}{*}{$\leq 2$} & Vegetative & 66 \\
\hline & Fruiting, terminal position & 73 \\
\hline & Fruiting, lateral position & 65 \\
\hline & $\begin{array}{l}\text { Fruiting with a second } \\
\text { growth flush }\end{array}$ & 55 \\
\hline \multirow[t]{4}{*}{1} & Vegetative & 66 \\
\hline & Fruiting, terminal position & 76 \\
\hline & Fruiting, lateral position & 69 \\
\hline & $\begin{array}{l}\text { Fruiting with a second } \\
\text { growth flush }\end{array}$ & 64 \\
\hline \multicolumn{2}{|c|}{$\mathrm{LSD}_{0.05}$ shoot type for the same thinning treatment } & 12 \\
\hline \multicolumn{2}{|c|}{$\begin{array}{l}\mathrm{LSD}_{0.05} \text { thinning treatment for the same or } \\
\text { different shoot type }\end{array}$} & 15 \\
\hline
\end{tabular}

$P>F=0.51$ and 0.57 for 2003 and 2004, respectively). The lack of an interaction during the other 2 years between thinning treatment and shoot type suggests that cluster thinning and cluster removal would be equally effective thinning methods.

In 2003, the percentage of current-season shoots with pistillate flowers was similar among unthinned trees and those thinned to $\leq 2$ and 1 fruit/cluster (Table 3 ). Those that had been thinned to $\leq 3$ fruit/cluster had a smaller return bloom than trees thinned to $\leq 2$ or 1 fruit/cluster. The crop load in 2002 was similar for the thinned trees, ranging from $63 \%$ to $69 \%$ fruiting shoots; thus cluster thinning in 2003 influenced total crop load more than initial flowering. This indicates that the largest cluster size that could be maintained to achieve maximum return bloom was $\leq 2$ fruit/cluster. In 2004, only unthinned trees and those thinned to 1 fruit/cluster differed in the percentage of current-season shoots fruiting. The percentage shoots that supported flowers in 2003 varied substantially among treatments; therefore, cluster thinning treatments were not related to total crop load.

Shoots with a second growth flush produced more shoots the following year than the other shoot types (Table 5). Over the 3 years, shoots with a second growth flush averaged $71 \%$ more new shoots annually than the other shoot types, substantially increasing the bearing surface compared with the other shoot types. Differences were inconsistent among the other three shoot types in new shoot production.

The total number of pistillate flowers produced the following year by shoots that had a second growth flush was greater than the other three shoot types during 2 of 3 years (Table 5). Shoots with a second growth flush averaged $63 \%$ more pistillate flowers than the other shoot types, only slightly less than the percentage increase in new shoots. Vegetative shoots produced more flowers the next year than bearing lateral shoots during 2 of 3 years. Bearing terminal shoots produced as many pistillate flowers the following year as shoots that had been vegetative and more than bearing lateral shoots.

The percentage of current-season shoots that flowered was also affected by the type of previous season's shoot from which they arose (Table 5). A greater percentage of current-season shoots flowered if they developed from previously vegetative shoots than from fruiting shoots with a second growth flush in 2004, but not 2003. Differences were inconsistent in the percentage of current-season flowering shoots arising from the other shoot types.

Cluster size the following year was larger if the previous year's bearing shoot had made a second growth flush than if the bearing shoot had not (Table 5). Vegetative shoots produced similar sized cluster to bearing shoots with a second growth flush in 2 of 3 years and larger than bearing shoots without a second growth flush.

Fruit cluster thinning treatments minimally affected nonstructural carbohydrates in the roots during January (Table 6). Total nonstructural carbohydrate and nonreducing sugar concentrations in the roots during January were unaffected by thinning treatment throughout the study. Reducing sugar was lower in roots $<1 \mathrm{~cm}$ diameter when clusters were thinned to one fruit than when not thinned during the first year of the study. Otherwise, reducing sugar concentration was unaffected by thinning treatment. The only time starch concentrations were different among treatments was the third year of the study in roots $<1 \mathrm{~cm}$ diameter, when concentrations were higher than the other treatments when clusters were thinned to one fruit.

Thinning treatments did not affect nonstructural carbohydrate concentrations in the shoots during January (data not shown). There were no interactions between thinning treatment and shoot type affecting January nonstructural carbohydrates in the shoots.

Nonstructural carbohydrate concentrations in January differed among shoot types (Table 7). Total nonstructural carbohydrates in vegetative shoots and bearing terminal shoots were similar in 2 of 3 years. Reducing sugar concentrations were similar each year, and nonreducing sugar and starch concentrations were similar in 2 of 3 years in vegetative shoots and bearing terminal shoots. Nonstructural carbohydrate concentration in bearing lateral shoots was only analyzed during the third year of the study. The total nonstructural carbohydrate concentration and starch concentration in bearing lateral shoots were similar to vegetative and bearing terminal shoots. Reducing and nonreducing sugar concentrations varied inversely among the bearing lateral shoots compared with the vegetative and bearing terminal shoots. In shoots with a second growth flush, the second flush had substantially lower total nonstructural carbohydrates than the primary flush during 2 of 3 years. Reducing sugar, nonreducing sugar, and starch concentrations were lower in the second growth flush than the first growth flush during 2002. In 2003, only reducing sugar concentration was significantly different between the first and second growth flushes.

Organically bound $\mathrm{N}$ and $\mathrm{K}$ concentrations during dormancy in roots $<1 \mathrm{~cm}$ diameter or $\geq 1 \mathrm{~cm}$ diameter were unaffected by cluster thinning treatment (data not shown). However, there were differences in organically bound $\mathrm{N}$ and $\mathrm{K}$ concentrations 
Table 5. Influence of previous year's shoot type on development of new shoots, total flowers produced from 1-year-old branches, current-season shoots flowering and flower cluster size of pecan.

\begin{tabular}{|c|c|c|c|c|c|c|c|c|c|c|c|}
\hline \multirow{2}{*}{$\begin{array}{l}\text { Previous year's } \\
\text { shoot type }\end{array}$} & \multicolumn{3}{|c|}{$\begin{array}{l}\text { Current-season shoots/1-yr-old } \\
\text { branch (no.) }\end{array}$} & \multicolumn{3}{|c|}{$\begin{array}{l}\text { Pistillate flowers/1-yr-old } \\
\text { branch (no.) }\end{array}$} & \multicolumn{2}{|c|}{$\begin{array}{l}\text { Current-season shoots } \\
\text { flowering }(\%)\end{array}$} & \multicolumn{3}{|c|}{$\begin{array}{l}\text { Flower cluster size } \\
\text { (no./cluster) }\end{array}$} \\
\hline & 2002 & 2003 & 2004 & 2002 & 2003 & 2004 & 2003 & 2004 & 2002 & 2003 & 2004 \\
\hline Vegetative & $2.1 \mathrm{c}^{\mathrm{z}}$ & $2.1 \mathrm{~b}$ & $2.0 \mathrm{c}$ & $5.8 \mathrm{~b}$ & $4.2 \mathrm{ab}$ & $6.3 \mathrm{bc}$ & $44 \mathrm{a}$ & $57 \mathrm{a}$ & $4.4 \mathrm{~b}$ & $4.6 \mathrm{a}$ & $5.7 \mathrm{a}$ \\
\hline $\begin{array}{l}\text { Fruiting, lateral } \\
\text { position }\end{array}$ & $2.2 \mathrm{bc}$ & $1.7 \mathrm{c}$ & $2.1 \mathrm{c}$ & $4.4 \mathrm{c}$ & $2.4 \mathrm{c}$ & $5.2 \mathrm{c}$ & $37 \mathrm{a}$ & $55 \mathrm{a}$ & $3.9 \mathrm{c}$ & $3.7 \mathrm{~b}$ & $4.5 \mathrm{~b}$ \\
\hline
\end{tabular}

${ }^{\mathrm{z}}$ Means within columns followed by the same letter are not significantly different by Duncan's multiple range test, $5 \%$ level.

Table 6. Influence of pecan fruit cluster thinning on nonstructural carbohydrates in large and small roots.

\begin{tabular}{|c|c|c|c|c|c|c|}
\hline \multirow{3}{*}{$\begin{array}{l}\text { Fruit cluster thinning } \\
\text { treatment (fruit/cluster) }\end{array}$} & \multicolumn{6}{|c|}{ Nonstructural carbohydrates (\% dry wt) } \\
\hline & \multicolumn{3}{|c|}{ Roots $<1 \mathrm{~cm}$ diam } & \multicolumn{3}{|c|}{ Roots $\geq 1 \mathrm{~cm}$ diam } \\
\hline & 2002 & 2003 & 2004 & 2002 & 2003 & 2004 \\
\hline & \multicolumn{6}{|c|}{ Reducing sugar } \\
\hline$\leq 3$ & $7.14 \mathrm{ab}$ & $9.78 \mathrm{a}$ & $8.52 \mathrm{a}$ & $4.41 \mathrm{a}$ & $10.08 \mathrm{a}$ & $5.48 \mathrm{a}$ \\
\hline$\leq 2$ & $5.82 \mathrm{ab}$ & $10.70 \mathrm{a}$ & $7.29 \mathrm{a}$ & $5.36 \mathrm{a}$ & $9.60 \mathrm{a}$ & $4.94 \mathrm{a}$ \\
\hline 1 & $4.96 \mathrm{~b}$ & $10.43 \mathrm{a}$ & $7.21 \mathrm{a}$ & $3.73 \mathrm{a}$ & $9.50 \mathrm{a}$ & $6.50 \mathrm{a}$ \\
\hline Unthinned & $13.78 \mathrm{a}$ & $10.44 \mathrm{a}$ & $16.64 \mathrm{a}$ & $3.22 \mathrm{a}$ & $13.40 \mathrm{a}$ & $15.19 \mathrm{a}$ \\
\hline$\leq 3$ & $13.22 \mathrm{a}$ & $11.52 \mathrm{a}$ & $18.95 \mathrm{a}$ & $5.38 \mathrm{a}$ & $15.09 \mathrm{a}$ & $13.76 \mathrm{a}$ \\
\hline$\leq 2$ & $12.42 \mathrm{a}$ & $11.27 \mathrm{a}$ & $17.66 \mathrm{a}$ & $4.89 \mathrm{a}$ & $14.87 \mathrm{a}$ & $14.29 \mathrm{a}$ \\
\hline \multirow[t]{2}{*}{1} & $12.47 \mathrm{a}$ & $12.40 \mathrm{a}$ & $17.94 \mathrm{a}$ & $4.46 \mathrm{a}$ & $15.75 \mathrm{a}$ & $13.63 \mathrm{a}$ \\
\hline & \multicolumn{6}{|c|}{ Starch } \\
\hline Unthinned & $2.57 \mathrm{a}$ & 0.66 & $0.44 \mathrm{~b}$ & $7.07 \mathrm{a}$ & $1.40 \mathrm{a}$ & $2.27 \mathrm{a}$ \\
\hline Unthinned & $24.26 \mathrm{a}$ & $21.59 \mathrm{a}$ & $23.76 \mathrm{a}$ & $12.91 \mathrm{a}$ & $24.76 \mathrm{a}$ & $23.89 \mathrm{a}$ \\
\hline$\leq 3$ & $22.56 \mathrm{a}$ & $21.37 \mathrm{a}$ & $27.95 \mathrm{a}$ & $17.13 \mathrm{a}$ & $25.83 \mathrm{a}$ & $20.85 \mathrm{a}$ \\
\hline$\leq 2$ & $21.26 \mathrm{a}$ & $22.43 \mathrm{a}$ & $25.43 \mathrm{a}$ & $18.90 \mathrm{a}$ & $25.04 \mathrm{a}$ & $21.33 \mathrm{a}$ \\
\hline 1 & $19.36 \mathrm{a}$ & $23.27 \mathrm{a}$ & $26.43 \mathrm{a}$ & $15.46 \mathrm{a}$ & $26.29 \mathrm{a}$ & $22.24 \mathrm{a}$ \\
\hline
\end{tabular}

${ }^{\mathrm{z}}$ Means within column and response variable followed by the same letter are not significantly different at the 5\% level by Duncan's multiple range test.

in the shoot types tested (Table 8). Organically bound $\mathrm{N}$ concentrations were similar in vegetative shoots and bearing terminal shoots in 2002. In 2003 and 2004, vegetative shoots had a lower concentration of organically bound $\mathrm{N}$ than did bearing terminal shoots. Nitrogen concentration in bearing lateral shoots was similar to that in bearing terminal shoots and greater than that in vegetative shoots in 2004. Shoots with a second growth flush had a higher $\mathrm{N}$ concentration in the second growth flush than the first flush during all 3 years.

Potassium concentrations were higher in bearing terminal shoots than in vegetative shoots 2 of 3 years (Table 8). In 2004, $\mathrm{K}$ concentration in bearing lateral shoots was higher than in vegetative shoots or bearing terminal shoots. Shoots with a second growth flush had the highest $\mathrm{K}$ concentration in the second flush in 2 of 3 years.

\section{Discussion}

Pecan trees in this study demonstrated classic alternate bearing (Fig. 1). Fruit thinned by reducing cluster size improved subsequent pistillate flower production (Table 3). In both 2002 and 2004, a similar number of flowers/1-year-old branch were produced when clusters were thinned to three fruit or less. The largest cluster size to achieve maximum return bloom on current-season shoots was $\leq 3$ in 2004 and $\leq 2$ in 2003.

There was an interaction between thinning treatment and shoot type in 2002 affecting the percentage of flowering current season (Table 4). However, there were no interactions between cluster thinning treatment and shoot type affecting the flowering current-season shoots in 2003 and 2004. In addition, there were no interactions between thinning treatment and shoot type affecting total pistillate flowers/1-year-old branch. These data suggest that fruit thinning can be equally effective if entire clusters are removed or if fruit within a cluster are removed. For instance, if cluster thinning were particularly beneficial, there would be an improvement in total pistillate flower production and in the percentage of flowering current-season shoots from previous year's bearing shoots relative to those shoots that were vegetative. This would be detected as an interaction between 
Table 7. Nonstructural carbohydrate concentrations in selected shoot types of pecan during dormancy.

\begin{tabular}{|c|c|c|c|c|c|}
\hline \multirow[b]{2}{*}{ Year } & \multirow[b]{2}{*}{ Shoot type/position } & \multicolumn{4}{|c|}{ Nonstructural carbohydrates (\% dry wt) } \\
\hline & & Reducing sugar & Nonreducing sugar & Starch & $\begin{array}{c}\text { Total nonstructural } \\
\text { carbohydrates }\end{array}$ \\
\hline \multirow[t]{3}{*}{2002} & Vegetative & $4.66 \mathrm{ab}$ & $11.80 \mathrm{a}$ & $0.91 \mathrm{a}$ & $17.44 \mathrm{ab}$ \\
\hline & Fruiting, first growth flush section & $5.68 \mathrm{a}$ & $12.57 \mathrm{a}$ & $1.01 \mathrm{a}$ & $19.26 \mathrm{a}$ \\
\hline & Fruiting, second growth section & $1.05 \mathrm{c}$ & $7.29 \mathrm{~b}$ & $0.39 \mathrm{~b}$ & $8.72 \mathrm{c}$ \\
\hline \multirow[t]{3}{*}{2003} & Vegetative & $3.63 \mathrm{ab}$ & $11.06 \mathrm{a}$ & $1.20 \mathrm{a}$ & $15.89 \mathrm{a}$ \\
\hline & Fruiting, first growth flush section & $3.87 \mathrm{a}$ & $6.54 \mathrm{c}$ & $0.28 \mathrm{~b}$ & $10.69 \mathrm{c}$ \\
\hline & Fruiting, second growth section & $2.95 \mathrm{~b}$ & $5.48 \mathrm{c}$ & $0.27 \mathrm{~b}$ & $8.70 \mathrm{~d}$ \\
\hline \multirow[t]{4}{*}{2004} & Vegetative & $3.92 \mathrm{c}$ & $9.73 \mathrm{a}$ & $0.43 \mathrm{c}$ & $14.08 \mathrm{a}$ \\
\hline & Fruiting, terminal position & $4.32 \mathrm{c}$ & $9.31 \mathrm{a}$ & $0.45 \mathrm{c}$ & $14.08 \mathrm{a}$ \\
\hline & Fruiting, first growth flush section & $5.63 \mathrm{~b}$ & $4.26 \mathrm{c}$ & $0.97 \mathrm{~b}$ & $10.87 \mathrm{~b}$ \\
\hline & Fruiting, second growth section & $5.63 \mathrm{~b}$ & $4.47 \mathrm{c}$ & $1.20 \mathrm{a}$ & $11.30 \mathrm{~b}$ \\
\hline
\end{tabular}

${ }^{\mathrm{z}}$ Means within the same year and column followed by the same letter are not significantly different at the $5 \%$ level by Duncan's multiple range test.

Table 8. Organically bound $\mathrm{N}$ and $\mathrm{K}$ in selected shoot types of pecan during dormancy.

\begin{tabular}{llll}
\hline & & \multicolumn{2}{c}{$\begin{array}{c}\text { Elemental concn } \\
\text { Y\% dry wt) }\end{array}$} \\
\cline { 3 - 4 } 2002 & Shoot type/position & $\mathrm{N}$ & $\mathrm{K}$ \\
\hline \multirow{2}{*}{2003} & Vegetative & $0.98 \mathrm{a}$ & $0.36 \mathrm{~b}$ \\
& Fruiting, terminal position & $1.03 \mathrm{a}$ & $0.41 \mathrm{a}$ \\
& Fruiting, first growth flush section & $0.90 \mathrm{~b}$ & $0.29 \mathrm{c}$ \\
& Fruiting, second growth section & $0.99 \mathrm{a}$ & $0.41 \mathrm{a}$ \\
& Vegetative & $0.87 \mathrm{bc}$ & $0.38 \mathrm{c}$ \\
& Fruiting, terminal position & $1.04 \mathrm{a}$ & $0.47 \mathrm{a}$ \\
& Fruiting, first growth flush section & $0.83 \mathrm{c}$ & $0.33 \mathrm{~d}$ \\
& Fruiting, second growth section & $0.89 \mathrm{~b}$ & $0.42 \mathrm{~b}$ \\
& Vegetative & $0.88 \mathrm{c}$ & $0.45 \mathrm{c}$ \\
& Fruiting, terminal position & $1.11 \mathrm{a}$ & $0.46 \mathrm{c}$ \\
& Fruiting, first growth flush section & $0.83 \mathrm{~d}$ & $0.60 \mathrm{a}$ \\
& Fruiting, second growth section & $0.94 \mathrm{~b}$ & $0.41 \mathrm{c}$ \\
& Fruiting, lateral position & $1.07 \mathrm{a}$ & $0.51 \mathrm{~b}$ \\
\hline
\end{tabular}

$\overline{{ }^{2} \text { Means within the same year and column followed by the same letter }}$ are not significantly different at the $5 \%$ level by Duncan's multiple range test.

thinning treatment and shoot type. However, total flower production each year and flowering current-season shoots in 2003 and 2004 was only associated with the main effect of the thinning treatment and not the interaction of thinning by shoot type. This suggests that improved flowering of all shoot types resulted from a reduction in the total crop load rather than smaller fruit clusters.

Incorporating cluster size targets into crop load recommendations to improve nut quality (Table 2) was not supported by these data, and improvement in return bloom was only supported once in 3 years over two variables. Rohla et al. (2005) reported weak or nonsignificant relationships for different shoot types between cluster size and kernel percentage. These results and those reported earlier (Rohla et al., 2005) indicate that pecan fruit load goals based on the percentage of bearing shoots (Smith et al., 1993) are adequate.

Vegetative shoots and bearing terminal shoots produced a similar number of flowers and percentage of flowering current- season shoots the following year (Table 5). Bearing lateral shoots produced fewer flowers than vegetative shoots 2 of 3 years and fewer fruiting current-season shoots during one year. Shoots with a second growth flush produced more flowers and fruiting current-season shoots than vegetative shoots 2 of 3 years. These data demonstrate that the position (terminal or lateral) of a bearing shoot on a branch affects its ability to produce flowers and fruiting shoots the following year. Wood (1995) reported that a larger percentage of current-season terminal shoots than lateral shoots flowered following fruit thinning. Also, return bloom of lateral shoots was reduced earlier in the growing season than terminal shoots by retaining fruit. Thus, the position of the shoot on a branch affects its ability to produce flowering shoots the following year and the current-season shoots that are produced are more likely to flower if they are in the terminal position. Shoots with a second growth flush were the most productive shoot type, supporting management recommendations that promote vigorous trees to achieve consistent production.

Abundant stored carbohydrates in the roots during the winter typically have been considered a key factor to reduce alternate bearing (Malstrom, 1974; Smith and Waugh, 1938; Wood, 1989, 1991; Worley, 1979a, 1979b). However, we found no relationship between nonstructural carbohydrates in the roots during January (Table 6) with the thinning treatments, although the thinning treatments improved return bloom (Table 3 ). There was also no relationship between thinning treatment and nonstructural carbohydrates in the shoots (data not shown). Scientists have also speculated that the amount of stored $\mathrm{N}$ might be closely associated with alternate bearing (Goff et al., 2001; Kraimer et al., 2004; Wood, 2001a), although studies on pecan have shown little response or a negative response to fall applied N (Acuña-Maldonado et al., 2003; Smith et al., 2004). Because $\mathrm{K}$ plays a critical role in carbohydrate and $\mathrm{N}$ transport, we also monitored root concentrations to determine if $\mathrm{K}$ was associated with crop thinning. There was no effect of thinning treatment either on organically bound $\mathrm{N}$ or on $\mathrm{K}$ stored in the root system during January. Trees in this study were alternate bearing (Fig. 1) and responded to fruit thinning (Tables 3 and 4), suggesting that factors other than nonstructural carbohydrates, organically bound $\mathrm{N}$, and $\mathrm{K}$ contributed to their irregular bearing. 
These data suggest that a growth regulator(s) associated with developing fruit is a key component regulating pistillate flower induction and consequently bearing consistency. High concentrations of nonstructural carbohydrates did not ensure bearing consistency or regulate flowering per se. Carbohydrate availability can become critical when crops are so excessive that tree survival is questionable (Wood, 2001b). However, in such situations, pistillate flower induction is unlikely, so growth regulator(s) from developing fruit prevented flower induction before nonstructural carbohydrates impacted development.

Premature defoliation can virtually eliminate pistillate flowers the following spring (Hinrichs, 1962; Worley, 1979a). This was attributed to depletion of nonstructural carbohydrates (Worley, 1979b). However, when trees were defoliated in August or early September, the trees refoliated, restoring nonstructural carbohydrate concentrations to that of the control by November, but subsequent-year flowering was eliminated. Wood et al. (2003) reported that the pecan alternate bearing index was not related to fruit ripening date or nut volume. There was a negative relationship between postripening foliation period and the alternate bearing index. These results suggest little role for nonstructural carbohydrates regulating alternate bearing. However, they pointed out the cultivars with late fruit ripening maintained healthier foliage with a greater photoassimilation rate that might allow greater accumulation of assimilate reserves. Two alternative hypotheses that are compatible with results in this study and previous studies are proposed to explain how premature defoliation or senescent foliage might affect subsequent flowering. First, leaf loss could induce a short-term carbohydrate shortage that might cause induced (reproductive) meristems to revert to a vegetative state. Second, growth regulator(s) produced by the leaves are required to maintain stability of the reproductive meristem. Removal of the growth regulator source by defoliation or premature senescence causes reversion of the induced meristem to the vegetative state.

Nitrogen was not limiting in this study, yet trees displayed classic alternate bearing. Pecan trees store large quantities of $\mathrm{N}$ that can be mobilized on the basis of demand (AcuñaMaldonado et al., 2003). Fruit typically remove a relative small amount of the tree's N. Pecan trees that are adequately supplied with $\mathrm{N}$ are unlikely to respond to fall-applied $\mathrm{N}$, especially when it is common to require two or more years to reduce yield by withholding N (Smith, 2002; Worley, 1974, 1990).

\section{Literature Cited}

Acuña-Maldonado, L.E., M.W. Smith, N.O. Maness, B.S. Cheary, and B.L. Carroll. 2003. Influence of $\mathrm{N}$ application time on nitrogen absorption, partitioning, and yield of pecan. J. Amer. Soc. Hort. Sci. 128:155-162.

Amling, H.J. and K.A. Amling. 1983. Physiological differentiation of pistillate flowers of pecan and cold requirements for their initiation. J. Amer. Soc. Hort. Sci. 108:195-198.

Barnett, J. and E.A. Mielke. 1981. Alternate bearing: a re-evaluation. Pecan South 8(1):20-23.

Brooks, O.L. and R. Livingston. 1962. A progress report on results of fertility studies with pecan. Proc. Southeastern Pecan Growers' Assn. 55:44-47.

Diver, S.G. and M.W. Smith. 1984. Influence of fruit development on seasonal elemental concentrations and distribution in fruit and leaves of pecan. Commun. Soil Sci. Plant Anal. 15:619-637.
Goff, B., M. Nesbitt, and C. Browne. 2001. Late season fertilization: an exciting new development for the pecan industry. Proc. Southeastern Pecan Growers' Assn. 94:91-93.

Haeder, H.E. 1977. Effects of potassium on phloem loading and transport. Fertilizer use and production of carbohydrates and lipids. Proc. Colloquium Intl. Potash Inst. 13:115-121.

Hinrichs, H.A. 1962. Pecan industry and some research developments in Oklahoma. Northern Nut Growers' Assn. 58:80-85.

Hodge, J.E. and B.T. Hofreiter. 1962. Determination of reducing sugars and carbohydrates, p. 300-394. In: R.L. Whistler and J.L. Wolfrom (eds.). Methods in carbohydrate chemistry. Vol. 1. Academic Press, New York.

Horowitz, W. 1980. Official methods of analysis of the association of analytical chemists. 13th ed. Assn. Offic. Anal. Chemists, Washington, D.C.

Hunter, J.H. 1964. Time of applying nitrogen to pecan trees in sod. Proc. Southeastern Pecan Growers' Assn. 57:18-22.

Hunter, J.H. and H.E. Hammar. 1947. The results of applying different fertilizers to the Moore variety of pecan over a ten-year period. Proc. Southeastern Pecan Growers' Assn. 40:10-32.

Hunter, J.H. and H.E. Hammar. 1956. Relation of oil content of pecan kernels to chemical components of leaves as a measurement of nutrient status. Soil Sci. 82:261-269.

Hunter, J.H. and H.E. Hammar. 1961. Effects of different grades and rates of fertilizers applied to Schley pecan trees as influenced by other factors. Proc. Southeastern Pecan Growers' Assn. 54:29-41.

Kraimer, R.A., W.C. Lindemann, and E.A. Herrera. 2004. Recovery of late-season ${ }^{15} \mathrm{~N}$-labeled fertilizer applied to pecan. HortScience 39:256-260.

Krezdorn, A.H. 1955. The nutrient status of pecan leaves in relation to alternate bearing. Proc. Texas Pecan Growers' Assn. 34:43-53.

Malstrom, H.L. 1974. The relationship of stored reserves to yield in mature pecan trees. Proc. Western Pecan Conf. 8:65-69.

Mengel, K. 1980. Effect of potassium on the assimilate conduction to storage tissue. Ber. Dtsch. Bot. Ges. 93:353-362.

Mengel, K. and H. Haeder. 1977. Effect of potassium supply on the rate of phloem sap exudation and the composition of phloem sap of Ricinus communis. Plant Physiol. 59:282-284.

Monselise, S.P. and E.E. Goldschmidt. 1982. Alternate bearing in fruit trees. Hort. Rev. (Amer. Soc. Hort. Sci.) 4:128-173.

Reid, W., S.M. Huslig, M.W. Smith, N.O. Maness, and J.L. Whitworth. 1993. Fruit-removal time influences return bloom in pecan. HortScience 28:800-802.

Rohla, C.T., M.W. Smith, and N.O. Maness. 2005. Effects of cluster size and shoot type on characteristics of pecan nuts. HortScience 40:1300-1303.

Skinner, J.J. 1922. Influence of fertilizers on the yield, size and quality of pecans. Proc. Georgia-Florida Pecan Growers' Assn. 16:50-56.

Smith, C.L. and J. Hamilton. 1937. Effects of nitrogen fertilizer on growth and yield of pecan trees growing in unproductive sandy soil. Proc. Texas Pecan Growers' Assn. 17:25-31.

Smith, C.L. and J.G. Waugh. 1938. Seasonal variations in the carbohydrate and nitrogen content of roots of bearing pecan trees. J. Agr. Res. 57:449-460.

Smith, M.W. 2002. Influence of nitrogen application time on nitrogen absorption, partitioning and yield of pecan. Oklahoma Pecan Growers' Assn. 72:40-41.

Smith, M.W. 2005. Understanding alternate bearing. Pecan South 38(10):32-37.

Smith, M.W. and J.C. Gallott. 1990. Mechanical thinning of pecan fruit. HortScience 25:414-416.

Smith, M.W., B.L. Carroll, and B.S. Cheary. 2004. Response to pecan to nitrogen rate and nitrogen application time. HortScience 39:1412-1415.

Smith, M.W., P.L. Ager, and D.S.W. Endicott. 1985. Effect of nitrogen and potassium on yield, growth, and leaf elemental concentration of pecan. J. Amer. Soc. Hort. Sci. 110:446-450.

Smith, M.W., R.W. McNew, P.L. Ager, and B.C. Cotton. 1986. Seasonal changes in the carbohydrate concentration in pecan shoots 
and their relationship to flowering. J. Amer. Soc. Hort. Sci. 111:558561.

Smith, M.W., W. Reid, B. Carroll, and B. Cheary. 1993. Mechanical fruit thinning influences fruit quality, yield, return fruit set, and cold injury of pecan. HortScience 28:1081-1084.

Sparks, D. 1968. Some effects of nitrogen on young pecan trees. Proc. Southeastern Pecan Growers' Assn. 61:93-102.

Sparks, D. 1974. The alternate fruit bearing problem in pecans. Northern Nut Growers' Assn. 47:145-158.

Sparks, D. 1975. Alternate fruit bearing - a review. Pecan South 2(2):44-65.

Sparks, D. 1977. Effects of fruiting on scorch, premature defoliation, and nutrient status of 'Chickasaw' pecan leaves. J. Amer. Soc. Hort. Sci. 102:669-673.

Sparks, D. 1979. Physiology—site, growth, flowering, fruiting, and nutrition, p. 211-239. In: R.A. Jaynes (ed.). Nut tree culture in North America. Northern Nut Tree Growers' Assn., Hamden, Conn.

Sparks, D. 1986. Pecan, p. 323-339. In: S.P. Monselise (ed.). CRC handbook of fruit set and development. CRC Press, Boca Raton, Fla. Sparks, D. 2000. Fruit set in pecan, Carya illinoinensis. Acta Hort. 527:35-48.

Sparks, D. 2003a. Growth, flowering, and fruiting, p. 273-316. In: D.W. Fulbright (ed.). A guide to nut tree culture in North America. Vol. 1. Northern Nut Tree Growers' Assn., Saline, Mich.

Sparks, D. 2003b. Revisiting the literature: timing fertilizer application for pecan. Pecan South 36(6):12-15.

Taylor, R.W. 1930. Influence of fertilizer treatments on yield and quality of pecans. Natl. Pecan Assn. Bul. 29:18-22.

von Broembsen, S. and P. Mulder. 2005. Commercial pecan disease and insect control-2006. Oklahoma Coop. Ext. Ser. CR-6209.

Vreugdenhil, D. 1985. Source-to-sink gradient of potassium in the phloem. Planta 163:238-240.

Wood, B.W. 1984. Influence of paclobutrazol on selected growth and chemical characteristics of young pecan seedlings. HortScience 19:837-839.
Wood, B.W. 1989. Pecan production responds to root carbohydrates and rootstock. J. Amer. Soc. Hort. Sci. 114:223-228.

Wood, B.W. 1991. Alternate bearing in pecan, p. 180-190. In: B.W. Wood and J.A. Payne (eds.). Pecan husbandry: challenges and opportunities. First National Pecan Workshop Proc., U.S. Department of Agriculture, Agricultural Research Service, ARS-96.

Wood, B.W. 1995. Relationship of reproductive and vegetative characteristics of pecan to previous-season fruit development and post ripening foliation period. J. Amer. Soc. Hort. Sci. 120:635-642.

Wood, B.W. 2001a. Managing nitrogen in pecan orchards. Proc. Southeastern Pecan Growers' Assn. 94:153-159.

Wood, B.W. 2001b. Atypical symptoms of cold damage to pecan. HortScience 36:298-301.

Wood, B.W. 2003. Pecan production in North America. Southwest. Entomologist 27:1-19.

Wood, B.W. and J.L. McMeans. 1981. Carbohydrate changes in various organs of bearing and nonbearing pecan trees. J. Amer. Soc. Hort. Sci. 106:758-761.

Wood, B.W., P.J. Conner, and R.E. Worley. 2003. Relationship of alternate bearing intensity in pecan to fruit and canopy characteristics. HortScience 38:361-366.

Wood, B.W., P.J. Conner, and R.E. Worley. 2004. Insight into alternate bearing of pecan. Acta Hort. 636:617-629.

Worley, R.E. 1974. Effect of N, P, K, and lime on yield, nut quality, tree growth, and leaf analysis of pecan (Carya illinoensis W). J. Amer. Soc. Hort. Sci. 99:49-57.

Worley, R.E. 1979a. Pecan yield, quality, nutlet set, and spring growth as a response of time of fall defoliation. J. Amer. Soc. Hort. Sci. 104:192-194.

Worley, R.E. 1979b. Fall defoliation date and seasonal carbohydrate concentration of pecan wood tissue. J. Amer. Soc. Hort. Sci. 104:195-199.

Worley, R.E. 1990. Long-term performance of pecan trees when nitrogen application is based on prescribed threshold concentrations in leaf tissue. J. Amer. Soc. Hort. Sci. 115:745-749. 